\title{
SOME NEW SYNONYMY IN THE HAEMOGAMASIDAE, LAELAPTIDAE AND DIPLOGYNIIDAE INDICATED BY AN EXAMINATION OF BANKS' TYPES OF MESOSTIGMATA (ACARINA)
}

\author{
By Donald E. Johnston \\ Institute of Acarology, Department of Zoology, \\ University of Maryland
}

During the course of a study of certain of the Banks mite types in the collection of the Museum of Comparative Zoology at Harvard College some cases of obvious synonymy were found. Two of these cases sink Banks' names; the remainder result in the establishment of his names as senior synonyms. In addition to those of Banks, the types of Ewing's, Furman's and Hicks' species (all in U.S. National Museum) were examined in connection with this work. I am grateful to Drs. H. W. Levi and W. L. Brown for arranging for me to study the Harvard collection and for their many kindnesses during my visit.

The following lectotype designations are not as precise as one would wish. The Banks types in the Museum of Comparative Zoology are not numbered and most names are represented by cotypes. All of the suspected and certain type slides are arranged alphabetically according to species and kept as a unit in the Arachnida collection of the Museum. Thus the lectotypes designated herein will be found labeled as such in their proper place in the alphabetical filing scheme. It may also be noted here that some of Banks' species (none of those treated herein) are represented by cotypes in both the MCZ and the Acarina collection of the U.S. National Museum. The same is true of Jacot's material which has been divided evenly between these museums.

\section{HaEmogamasidae}

\section{Haemogamasus longitarsus (Banks) Comb. Nov.}

Laclaps longitarsus Banks, I9IO. Proc. Ent. Soc. Wash. I2 ( I):5. Ex mole's nest, Falls Church, Virginia. Lectotype in MCZ.

Haemogamasus barberi Ewing, 1925. Proc. Biol. Soc. Wash. 38: I40. Ex nest of small mammal; Maryland shore of Potomac River, near Plummer Island. Type in U.S.N.M. New SYNONYMY.

Haernogamasus microti Ewing, 1925. Proc. Biol. Soc. Wash. 38 : 14I. Ex Microtus pennsylvanicus, Bronxville, New York. Type in U.S.N.M. [= barberi according to Keegan, I95 I :249]

Remarks: The type series of Laelaps longitarsus consisted of eight 
specimens. These have been remounted individually and a female is here designated as lectotype (indicated on slide label).

\section{Eulaelaps stabularis (Koch)}

Gamasus stabularis Koch, I 836. Crust, Myr. Arachnid. Deutschlands, Fasc. 27, No. I Host unknown; Regensburg. Type unknown.

Laelaps pedalis Banks, i 909. Proc. Ent. Soc. Wash. I I (3) : I36. Ex chipmunk; Guelph, Ontario, Canada. Type in MCZ. NEw SYNONYMY.

Laelaps propheticus Banks, I909. Ibid:I36 Ex groundhog; Guelph, Ontario. Lectotype in MCZ. NEW SYNONYMY.

Remarks: The type slide of $L$. propheticus contained one female $E$. stabularis (here designated lectotype) and two Haemolaelaps glasgowi (Ewing). Laelaps pedalis is represented by a single female. The concept of $E$. stabularis with which Banks' names are synonymized is that of Strandtmann and Wharton (1958:127) and Bregatova ( 1956:100).

\section{LAELAPTIDAE}

Androlaelaps frontalis (Banks) Comb. Nov.

Gamasus frontalis Banks, I9ro. Proc. Ent. Soc. Wash. I2 (3) :3. Ex Perognathus; Los Palmos, 3500 feet, Santa Rosa Mountains, California. Lectotype in $\mathrm{MCZ}$.

Androlaelaps sinuosa Furman, I954. Pan-Pacific Ent. 30 (2) : I 20. Ex Pergognathus sp., probably fallax fallax, at Pigeon Pass, Riverside County, California. Type in U.S.N.M. NEw Synonymy.

Remarks: The type slide bore four females and two males of this striking laelaptid. These have been remounted individually and a female is here designated lectotype (indicated on slide label). Banks' placement of this species in Gamasus (presumably because of the large size and calcarate femora of legs II) is undoubtedly the reason for its having been overlooked by workers in the Laelaptidae.

\section{Diplogynimae}

Neolobogynium americana (Banks) Comb. Nov.

Celaenopsis americana Banks, 1906. Proc. Ent. Soc. Wash. 7: 137. Ex Histerid beetle (Hololepta sp.) at Indianapolis, Indiana. Lectotype in $\mathrm{MCZ}$.

Neolobogynium lateriseta Hicks, 1957. Proc. Iowa Acad. Sci. 64: 6i6. Host unknown; Ames, Iowa. Type in U.S.N.M. NEW SYNONYMY. 
Remarks: Banks' type slide contained 18 adults of both sexes of this common mite associate of Hololepta (Histeridae). These have been remounted and a female is here designated lectotype (indicated on slide label).

\section{References Cited}

Bregatova, N. G. 1956. Gamasid Mites (Gamasoidea). Acad. Sci. U.S.S.R., Moskow. 247 pp. [in Russian.]

KEEGAN, H. L. 1951. The mites of the subfamily Haemogamasinae (Acari: Laelaptidae). Proc. U. S. Nat. Mus. 101:203-268.

StrandTMANN, R. W. and G. W. Wharton. 1958. A manual of mesostigmatid mites parasitic on vertebrates. Contribution 4, Institute of Acarology, University of Maryland. i-xi+1-330+pls. 1-69. 

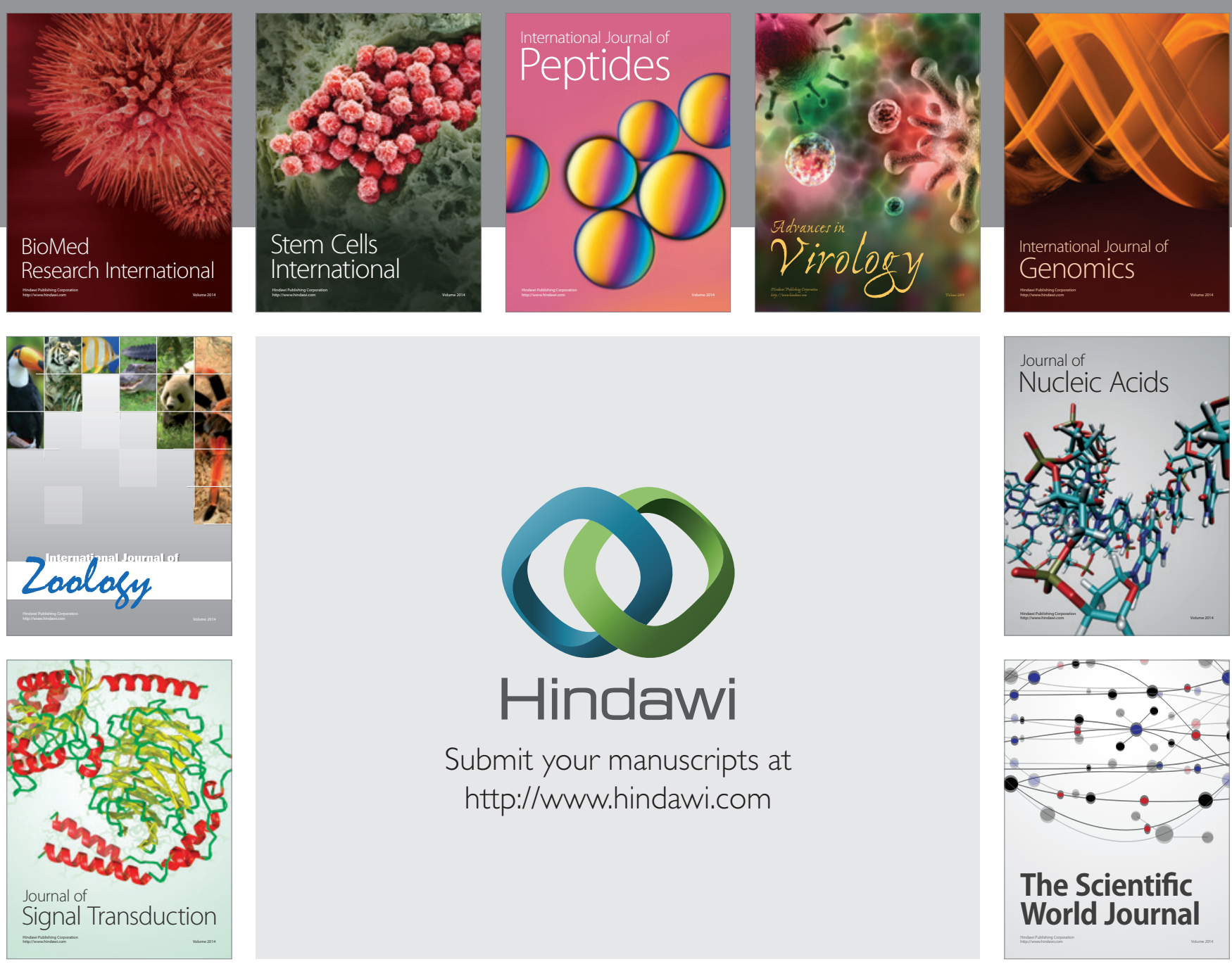

Submit your manuscripts at

http://www.hindawi.com
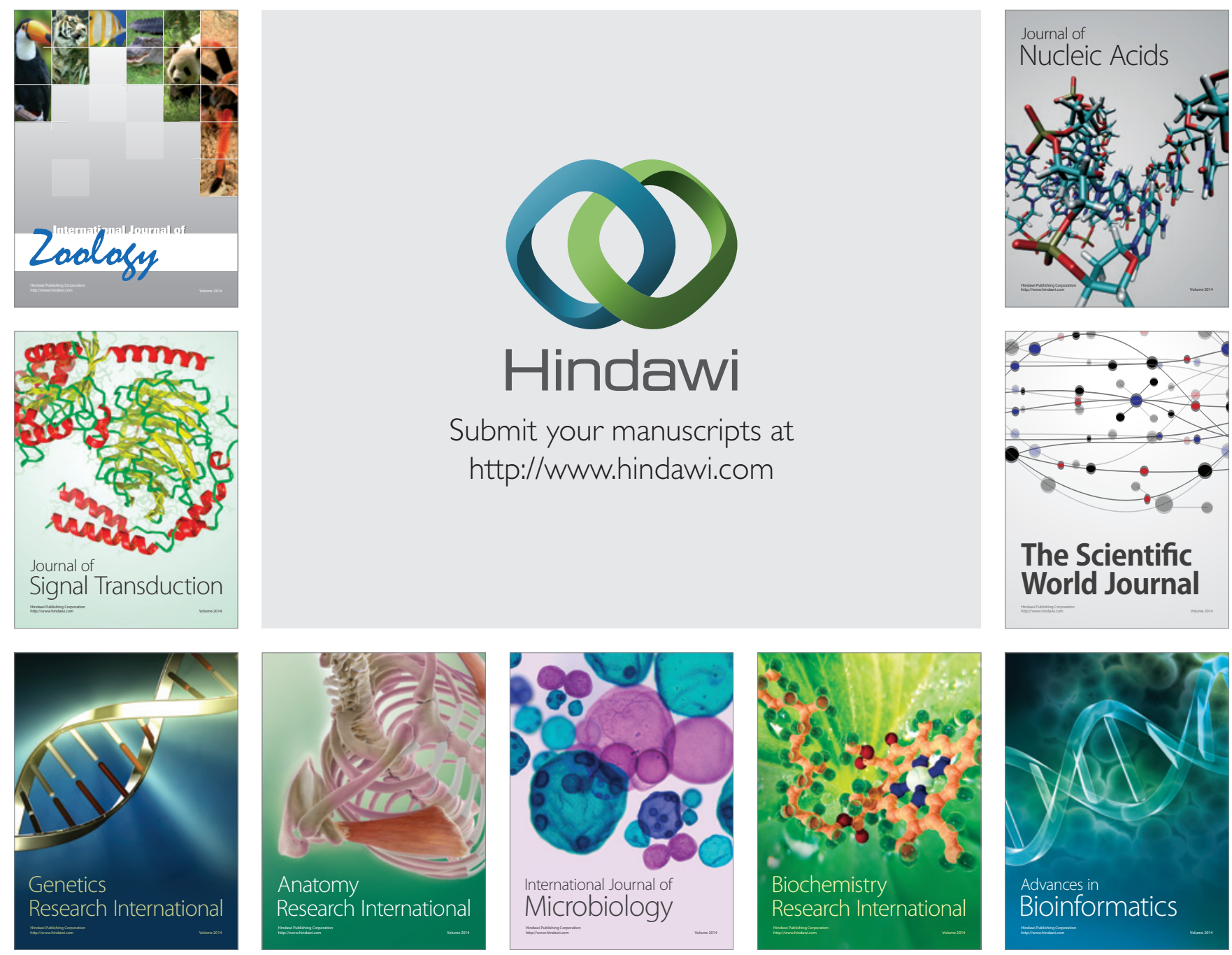

The Scientific World Journal
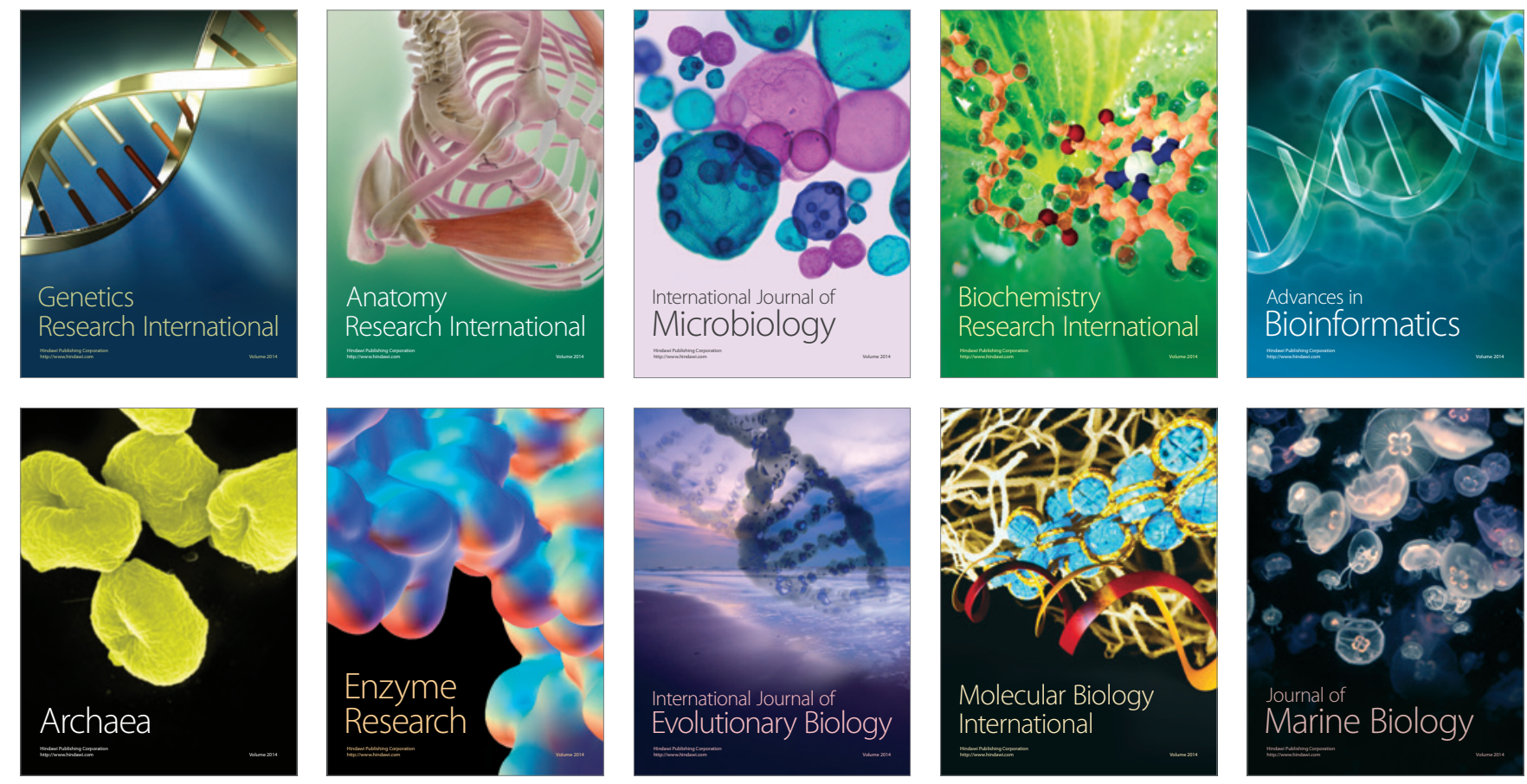